\title{
НОВІ ПРИГОДИ АРХЕТИПІВ
}

\section{B.I. Менжулін}

У монографії, що вийшла декілька років тому, ми намагалися виявити основні етапи та тенденції у вітчизняній рецепції спадщини відомого швейцарського мислителя К.-Г. Юнга $(1875-1961)^{1}$. Однак майже поза увагою залишився такий цікавий сегмент українського осмислення цієї постаті, як тексти «на правах рукопису», зокрема - дисертаційні роботи, подані на здобуття наукового ступеню доктора або кандидата наук. Перегляд тем дисертаційних досліджень, що були захищені в Україні протягом останніх років (у тому числі й після виходу монографії), дозволяє стверджувати, що тут є про що поговорити. Як виявляється, спадщина засновника аналітичної психології користується досить великою популярністю серед вітчизняних пошукувачів академічних ступенів. Зрозуміло, найчастіше до цієї проблематики звертаються дисертанти-психологи. Їхні тлумачення ідей та діяльності Юнга можуть бути предметом окремого дослідження. Що стосується даної статті, то вона присвячується розгляду того, за допомогою яких методів, з якими цілями та яким саме чином інтерпретувалися ідеї Юнга у дисертаціях, що були захищені виключно з філософських дисциплін.

В період з 1998 по 2004 р. в Україні з'явилося якнайменше сім нових кандидатів ${ }^{2}$ філософських наук, в дисертаціях яких важливу роль грали залучення та тлумачення тих чи інших елементів вчення К.-Г. Юнга. Саме ці роботи й складатимуть основний матеріал для нашого аналізу ${ }^{3}$.

\footnotetext{
${ }^{1}$ Менжулин В.И. Расколдовывая Юнга: от апологетики к критике.-К.: Сфера, 2002. Розвитку уявлень стосовно Юнга в українському інтелектуальному контексті в даній роботі присвячено окрему главу - «Украинский Юнг» (Там же. - С. 152-190).

2 Докторських дисертацій з подібною тематикою, наскільки відомо авторові даної статті, не було.

${ }^{3}$ Переважною мірою аналізуватимуться автореферати дисертаційних досліджень, однак в одному випадку ми звернемося й власно до тексту дисертації (робота Л.О. Забєліної - див. наступне посилання).
}

Актуальні проблеми духовності

(Відп. ред.: Я.В. Шрамко)

Кривий Ріг (2005), 111-128 
Найбільшу увагу привернула до себе, як і можна було очікувати, концепція архетипів колективного несвідомого. Слово «архетип» присутнє в назвах шести дисертацій, однак, зрозуміло, ступінь зацікавленості суто юнгівською проблематикою у різних авторів не є однаковою. Безпосередньо юнгівському вченню присвячено три дисертації: 1) «Архетип самості в контексті культурних традицій» (авторка- Л.О. Забєліна $)^{4} ; 2$ ) «Релігійно-культурологічна концепція К.Г. Юнга» $\left.(\text { автор - С.В.Бичатін })^{5} ; 3\right)$ «Феноменологія архетипу в системі соціокультурного освоєння колективного несвідомого (на матеріалах творчості К.Г. Юнга)» (автор - С.А. Маленко $)^{6}$. У двох дисертаціях спадщина Юнга була одним з провідних джерел: 1) «Механізми несвідомого соціального спотворення феноменології архетипу» (автор - А.Г. Некита $)^{7} ; 2$ ) «Міфопоетичне відтворення архетипу» (авторка-О.С. Колесник $)^{8}$. Тематика ще двох дисертацій перехрещується з юнгівською лише епізодично: 1) «Слово як архетип культури» $(\text { авторка - Н.О. Плахотнюк })^{9}$. 2) «Загальноіндоєвропейські міфологічнорелігійні архетипи та їх вияв в українській духовній традиції» (авторА.Б. Поцелуйко $)^{10}$.

\footnotetext{
4Забєліна Лідія Олександрівна. Архетип самості в контексті культурних традицій: Автореф. дис. канд. філос. наук (спеціальність 09.00.04-філософська антропологія, філософія культури) / Таврійський національний ун-т ім. В.І. Вернадського. - Сімф., 2004.-19 с. (Далі-Забеліна Л.О. Автореферат); Забелина Лидия Александровна. Архетип самости в контексте культурных традиций: Дис...канд. филос. наук / Таврийский национальный ун-т им. В.И. Вернадского. - Симф., 2004. - 218 с. (Далі - Забєліна Л.О. Дисертація). Автореферат роботи п. Забєліної надруковано українською мовою, а текст дисертації-російською. Ми цитуватимемо обидва джерела мовами оригіналів, тобто українською та російською відповідно.

${ }^{5}$ Бичатін Сергій Володимирович. Релігійно-культурологічна концепція К.Г. Юнга: Автореф. дис. . канд. філос. наук: (спеціальність 09.00.11- релігієзнавство) / Інститут філософії ім. Г.С. Сковороди НАН України. - К., 2002. - 18 с.

${ }^{6}$ Маленко Сергій Анатолійович. Феноменологія архетипу в системі соціокультурного освоєння колективного несвідомого (на матеріалах творчості К.Г. Юнга): Автореф. дис...канд. філос. наук: (спеціальність 09.00.03-соціальна філософія та філософія історії) / Інститут філософії ім. Г.С. Сковороди НАН України. - К., 1998. - 16 с.

${ }^{7}$ Некита Андрій Григорович. Механізми несвідомого соціального спотворення феноменології архетипу: Автореф. дис. . канд. філос. наук (спеціальність 09.00.03- соціальна філософія та філософія історії) / Інститут філософії ім. Г.С. Сковороди НАН України. - К., 2001.-16 с.

${ }^{8}$ Колесник Олена Сергіївна. Міфопоетичне відтворення архетипу: Автореф. дис. . канд. філос. наук (спеціальність 09.00.08-естетика) / Київський національний ун-т ім. Тараса Шевченка. - К., 2002. - 16 с.

${ }^{9}$ Плахотнюк Наталія Олексіївна. Слово як архетип культури: Автореф. дис. . . канд. філос. наук (спеціальність 09.00.04-філософська антропологія, філософія культури) / Інститут філософії ім. Г. Сковороди НАН України. - К., 2000. - 20 с.

${ }^{10}$ Поцелуйко Андрій Богданович. Загальноіндоєвропейські міфологічно-релігійні архетипи та їх вияв в українській духовній традиції: Автореф. дис...канд. філос. наук (спеціальність 09.00.11 - релігієзнавство) / Інститут філософії ім. Г.С. Сковороди НАН України.-K., 2004.-22 с.
} 
Більш за все цікавих для нашого дослідження дисертацій було захищено на базі Інституту філософії НАНУ ім. Г.С. Сковороди - п'ять, решта - в Національному університеті ім. Т.Г. Шевченка та в Таврійському національному університеті ім. В.І. Вернадського (по одній). Суто юнгівська або споріднена 3 нею тематика дисертації виявилася прийнятною в рамках чотирьох філософських спеціальностей: естетика - 1 робота; філософська антропологія, філософія культури -2 ; релігієзнавство -2 ; соціальна філософія та філософія історії-3.

Зі спеціальності «історія філософії, наскільки відомо авторові даної статті, протягом зазначеного періоду дисертацій, пов'язаних з Юнгом, не було. У зв'язку з цим одразу може виникнути питання: А чи варто взагалі розглядати, як інтерпретували Юнга дослідники, основною метою яких було не стільки автентичне та всебічне відтворення його думок, скільки формування на грунті останніх своїх власних естетичних, філософськоантропологічних, релігієзнавчих або соціально-філософських концепцій? Чи має сенс розглядати подібні факти використання як скільки-небудь значущі приклади інтерпретаціï?

На нашу думку, цілком можливо і навіть потрібно. Будь-яке використання чиїхось ідей (навіть просте цитування) вже $є$ інтерпретацією. Сама історія філософії великою мірою являє собою історію подібних інтерпретацій-використань. Деякі з них, навіть ті, що не можна визнати досконалими з суто історико-філософської точки зору, виявляються надзвичайно цікавими, показовими, іноді дуже плідними, а іноді-симптоматичними. Не виключено, що інтерпретації ідей Юнга, що містяться в роботах, обраних в якості матеріалу для даного дослідження, також чимось цікаві та примітні. Оцінити значення цих робіт з точки зору засвоєння, трансляції та трансформації ідей К.-Г. Юнга ми спробуємо за допомогою класифікації інтерпретацій-використань чужих концепцій, запропонованої відомим сучасним філософом Р. Рорті.

Рорті вважає, що інтерпретації (за його термінологією-критики) чужих ідей бувають трьох сортів - третього, другого та першого. «Третьосортний» критик - це критик у повсякденному, найбільш банальному і найменш привабливому розумінні цього слова: він спростовує ідеї мислителя, якого критикує, шляхом демонстрації їх невідповідності певній системі уявлень, яку він приймає за абсолютну істину. Саме такою критикою Юнга та психоаналізу в цілому займалися поборники «єдино вірного та вічного живого» вчення за радянських часів. «Другосортний» критик уникає такого одіозного підходу: він критикує героя свого дослідження не ззовні, а зсередини, тобто намагається виявити в його спадщині певні двозначності, непослідовності, неясності, протиріччя й таке інше. Такого роду прочитання є цілком припустимим як одна із складових серйозного історико-філософського дослідження. Однак, з точки зору Рорті, право 
називатися «першосортним» має лише той критик, який не зосереджується на недоліках системи, яку розглядає, на контексті, в якому вона розвивалася, а замість цього займається її «прагматичною реконтекстуалізацією», тобто намагається створити з неї щось принципово інше, наповнити її новим, більш перспективним з його точки зору, смислом. «Першосортному» критикові в принципі не дуже важливо, що мав на увазі той, кого він інтерпретує, в чому той мав рацію, а в чому помилявся. Критик, якого Рорті по-справжньому шанує, використовує ідеї інших мислителів задля створення своїх власних, більш переконливих (принаймні, на думку цього критика) метафор ${ }^{11}$.

Спробуємо розглянути обрані роботи українських дисертантів з урахуванням цієї класифікації. Чи можна знайти у головних героїв нашого дослідження приклади того, що Рорті називає критикою «третього сорту»? Несподіваний, але приємний факт: такого роду критики майже немає. На роль зовнішньої оціночної інстанції у деяких з дисертантів деінде висувається досить розмитий образ «сучасної науки». Однак, як правило, одразу ж стверджується, що іiї справжнім ідеалам юнгівські теорії ніяким чином не суперечать. Наприклад, один з дисертантів впевнений, що творчість Юнга «акумулює підсумки загально-філософських та психіатричних наукових досліджень» ${ }^{12}$, а інший проголошує Юнга творцем «нової системи віри» та «нової міфології ХХ століття», що здатні поєднати «релігійний досвід в його традиційному тлумаченні із новітніми науковими ідеями» ${ }^{13}$. Так, певні погляди творця нової міфології, за думкою одного $з$ дисертантів «відчули на собі обмеженість галузевої науки» ${ }^{14}$, але постраждала від цього, як вважає його колега, лише сама наука: «Чдові досягнення К.Г. Юнга ... дотепер не асимільовані у філософській науці, a ïx евристичні та пояснюючі можливості ще не усвідомлені» ${ }^{15}$. Врештірешт все стане на свої місця, бо архетипи, як стверджує ще один з авторів, «є джерелами усіх наймогутніших ідей-естетичних, релігійних, наукових, філософських, етичних тощо» ${ }^{16}$.

Цілком природним наслідком такого безмежного кредиту довіри (не Юнга треба повіряти наукою, а скоріше - науку Юнгом!) виявляється те, що в самих дисертаціях як беззаперечна істина подається уявлення, яке ще за півстоліття до смерті Юнга набуло статусу глибокої та дуже небезпечної помилки наукового розуму. Йдеться про його незмінну

\footnotetext{
11 Докладніше про це див.: Юлина Н.С. Ричард Рорти: разговор «через эпохи», «в эпохе» и историография философии // История философии. - М.: ИФРАН, 1997.№1.

${ }^{12}$ Некита А.Г. Вказ. праця. - С. 2.

${ }^{13}$ Бичатін C.В. Вказ. праця.- С. 4.

${ }^{14}$ Маленко С.А. Вказ. праця. - С. 2.

15 Забеліна Л.О. Автореферат.-С. 2.

${ }^{16}$ Колесник О.С. Вказ. праця.-С. 12 .
} 
прихильність вченню Ж.-Б.Ламарка про успадкування набутих ознак. Незважаючи на те, що вже не одне десятиліття всі шкільні підручники наголошують на тому, що ламаркізм несумісний із сучасною наукою, п. Забєліна твердить, що «Архетипы сложились за многие тысячелетия и испокон веков наследуются коллективным бессознательным» ${ }^{17}$; в роботі п. Маленка «розкривається значення архетипу як історично спадкоємного інстинкту» ${ }^{18} ;$ п. Некита говорить про «накопичуване несвідоме» ${ }^{19} ;$ п. Бичатін впевнений, що «колективне несвідоме - це образ світу як деяка його апріорність, що виникає з успадкованих структур мозку» ${ }^{20}$. Хто знає, може наші дисертанти мають рацію і з часом наука все ж таки визнає, що в мозку новонародженої дитини вже апріорно можуть бути наявні певні психічні інстинкти, які вид homo sapiens мав не з моменту свого виникнення, а накопичував протягом усієї своєї історії, тобто набував апостерiорним шляхом?

Щодо критики «другого сорту», то вона в роботах, обраних нами для розгляду, фактично відсутня. Можливо, це абсолютно природно, оскільки шукати протиріччя в юнгівській системі-завдання власне істориків філософії або психології, а не соціальних філософів, філософів культури, релігієзнавців або естетиків, які лише спираються на певні ідеї засновника цієї течії. Але, оскільки в творчості самого Юнга було безліч протиріч, неясностей, багато з них мимоволі проступають у роботах дисертантів у невідрефлексованому або напів-відрефлексованому вигляді. Так буває: якщо ти не хочеш інтерпретувати психоаналіз, він сам проінтерпретує тебе.

Наприклад, сам Юнг та його послідовники мали та мають великі утруднення $з$ дефініцією базового концепту їхньої системи віри - архетипів колективного несвідомого ${ }^{21}$. Однак автори досліджуваних робіт або не помічають цього взагалі, або, навпаки, повідомляють про те, що архетип може бути майже всім, чим завгодно, як про цілком нормальний факт, який ніяким чином не заважає їхньому власному дослідженню. Авторка роботи «Міфопоетичне відтворення архетипу» вважає, що архетипи «поєднують колективне та індивідуальне, інтерсуб'єктивне та суб'єктивне, загальнолюдське та етнічне, соціальне та культурне, набуте та спадкоємне, реальне та ідеальне...» ${ }^{22}$. Її колега, робота якої присвячена безпосе-

\footnotetext{
17 Забєліна Л.О. Дисертація.-С. 20.

18 Маленко С.А. Вказ. праця.-С. 4.

${ }^{19}$ Некита А.Г. Вказ. праця.- С. 8.

${ }^{20}$ Бичатін С.В. Вказ. праця.- С. 4.

${ }^{21}$ Про численні різночитання, що пов'язані з поняттям «архетипів колективного несвідомого», говорять майже всі дослідники Юнга, причому не тільки його критики, але й прихильники (див., напр., статтю «Архетип»: Сэмъюэлз Э., Шортер Б., Плот Ф. Критический словарь аналитической психологии К. Юнга. - М.: Эси, 1994.- С. 29-31).

22 Колесник О.С. Вказ. праця. - С. 8.
} 
редньо одному з архетипів колективного несвідомого (архетипу Самості), пропонує задовольнитися тим, що й сам Юнг визнавав принципову невизначеність фундаментальних понять своєї системи:

Сущность же бессознательной психики можно описать лишь с помощью парадоксов: «она личностна и безличностна, моральна и аморальна, справедлива и несправедлива, этична и неэтична, наделена тончайшим интеллектом и в то же время чрезвычайно сильна и крайне слаба» 23

Стосовно не менш проблематичного питання юнгівського вчення (Чи мають архетипи онтологічний статус?) між нашими дисертантами виникає заочна суперечка. Один з них говорить про «онтологічну місію архетипів» $^{24}$, другий заявляє, що однією $з$ теоретико-методологічних основ його роботи $\epsilon$ «юнгіанський принцип онтологізації феноменів колективного несвідомого» ${ }^{25}$, однак їм опонує їх колега, посилаючись при цьому на самого Юнга: «... заперечуючи у Бога онтологічний, трансцендентний, потойбічний статус, К.Г. Юнг замінює його іманентним, притаманним самій людині [архетипом Бога] і тлумачить його на інтрапсихічній основі» ${ }^{26}$. Підсумок цій неоголошеній мікро-дискусії підбиває О.С.Колесник, яка, як і у випадку з дефініцією сутності архетипу, виявляється прибічницею багатовекторності у розумінні справжнього статусу цього феномену:

В результаті дослідження з'ясовується, що все розмаїття філософсько-естетичних концепцій архетипу можна звести до трьох методологічних моделей розуміння феномену: а) як, перш за все, духовно-онтологічної, трансцендентної реальності, визначальної по відношенню до матеріального світу; б) як психологічної, іманентної реальності; причому відмежування обох типів розуміння не $\epsilon$ чітким, що робить логічним їх синтез: в) розуміння архетипу як відображення в людській душі об'єктивно існуючих структур буття, поєднання реального та ідеального, космічного та психічного ${ }^{27}$.

Різнобій, інспірований великою мірою знов-таки самим Юнгом, спостерігається й у визначенні гносеологічного статусу архетипів. Скажімо,

\footnotetext{
23 Забєліна Л.О. Дисертація.-С.18. У даному пасажі п.Забєліна цитує лист Юнга до Мертона Келсі (Цит. по: Аналитическая психология: Прошлое и настоящее / К.Г.Юнг, Э.Сэмюэлс, В.Одайник, Дж. Хаббак; Сост. В.В.Зеленский, А.М. Руткевич. - М.: Мартис, 1995.-С.211).

${ }^{24}$ Некита А.Г. Вказ. праця.-С. 2.

${ }^{25}$ Маленко С.А. Вказ. праця. - С. 4.

${ }^{26}$ Бичатін C.В. Вказ. праця. - С. 4 .

${ }^{27}$ Колесник О.С. Вказ. праця.-С. 8
} 
один з дисертантів вважає, що: «Онтологічні погляди К.Г. Юнга характеризуються визнанням психічної реальності як найбільш важливої. Гносеологічні підходи випливають з онтологічних і визначаються як сенсуалістські» ${ }^{28} .3$ яких онтологічних підходів випливає гносеологічний «сенсуалізм» Юнга, з цієї роботи дізнатися не вдається. Однак в іншій роботі $\epsilon$ куди більш правдоподібне твердження, з якого, поміж іншим, випливає й те, що про сенсуалізм у випадку з архетипами йтися не може ані за яких умов: «рраціональний та трансцендентний, архетип не може бути безпосередньо присутнім в артефактах культури. Він маніфестується в архетипний образ» ${ }^{29}$. Аналогічної точки зору дотримується й інша дисертантка: «Сам по себе архетип не входит в сознание, он не дан в чувственном опыте. Архетипы в этом смысле гипотетичны, представляют собой своего рода модель, позволяющую объяснить наличный опыт» ${ }^{30}$. Правда, подібні гносеологічні обмеження зовсім не заважають обом прибічницям непізнаваності архетипу в інших місцях говорити про нього як про визнаний факт ${ }^{31}$.

А як справи із встановленням кількості можливих значень того чи іншого архетипу? Їх певна кількість або безліч? Юнг чіткої відповіді на це запитання не дав. Отже, й тут у наших дисертантів залишився простір для вибору за власними уподобаннями. Якщо п. Маленко схиляється до повної невизначеності («Границі між архетипами розмиті, що й зумовлює перманентний взаємообмін їх певними якостями, який виражає домінуючу тенденцію розвитку несвідомого... $\gg^{32}$ ), то у п. Бичатіна навпаки: «архетипи мають неваріабельне число значень» ${ }^{33}$. Цей же автор говорить в одному місці, що юнгівське вчення «демонструє системну чіткість та струнку логіку» $^{34}$, однак згодом відзначає, що «погляди К.Г. Юнга на сутність Бога носять амбівалентний характер: важко розрізнити, коли він має на увазі Бога, а коли ,ідею Бога“" ${ }^{35}$.

Ще одну антиномію, яка присутня в працях Юнга (в одних він говорить, що існують тільки загальнолюдські архетипи, а в інших - що свої специфічні архетипи бувають також у рас та навіть окремих народів), ко-

\footnotetext{
${ }^{28}$ Бичатін С.В. Вказ. праця.-С. 7.

${ }^{29}$ Колесник О.С. Вказ. праця. - С. 9

30 Забеліна Л.О. Дисертація.-С. 29.

${ }^{31}$ На думку автора даної статті, що сформувалася після багатьох років вивчення спадщини Юнга, можливі дві абсолютно точні дефініції архетипу - позитивна та негативна. Позитивна: архетип - це у буквальному розумінні «Бог знає що» (оскільки тільки Бог може знати, що міститься там, куди не може потрапити людська свідомість); негативна: архетип-це ніщо, тобто ані що з того, що знає чи може знати людина.

${ }^{32}$ Маленко С.А. Вказ. праця.-С.8.

${ }^{33}$ Бичатін C.B. Вказ. праця. - С. 8.

${ }^{34}$ Бичатін C.B. Вказ. праця.- С. 3 .

${ }^{35}$ Бичатін С.В. Вказ. праця.- С. 11
} 
жен з дисертантів, хто торкається цього питання, розв'язує на свій власний смак. Автор роботи «Загальноіндоєвропейські міфологічно-релігійні архетипи та їх вияв в українській духовній традиції» вважає, що існують певні загальноіндоєвропейсъкі архетипи, які $\epsilon$ «невід'ємною складовою колективного несвідомого українського народу і знаходять свій вияв у феноменах української духовної традиції» ${ }^{36}$. Однак, Л.О. Забєліній більш підходить для цілей їі дослідження інша - протилежна - точка зору: «В отличие от личного бессознательного, коллективное бессознательное является абсолютно всеобщим, его содержания могут быть найдены повсюду...» ${ }^{37}$. Н.О. Плахотнюк не просто звужує юнгівську позицію щодо проблеми приналежності архетипів тим чим іншим групам людей («[Юнг] визначає архетипи як засадничі структури колективного підсвідомого, які виходять за межі етнічного та національного буття та становлять основу загальнолюдської символіки» ${ }^{38}$ ) але ще й вважає, що приклади альтернативного (трайбалістського) підходу, насправді теж наявного у Юнга, краще шукати у нашого співвітчизника: «Сучасний український дослідник Н. Хамітов визначає архетип культури як світоглядну основу проявів культурної творчості певного етносу або нації» 39 .

Щодо ролі архетипів та їхнього міфотворчого потенціалу в житті сучасного людства у наших дисертантів також немає повної згоди. О.С. Колесник відзначає, що «дослідження специфіки відтворення архетипних схем $\epsilon$ особливо важливим у наш час тотальної реміфологізації культури. В художній сфері це явище виявляється, зокрема, в насиченні мистецьких текстів відповідною символікою, аж до спроб створення нео-міфів як одного з засобів гармонізації кризової ситуації [у суспільстві]» ${ }^{40}$. П. Маленко в одному місці висловлюється приблизно в такому ж дусі: Міф, як найбільш цілісне, довершене утворення, вершина колективної несвідомої «творчості», єдино здатний гармонізувати стосунки між людиною та світом, людиною та людиною, людиною та суспільством, надаючи рафінований та наочний зразок сенсу людського буття, що гарантує найбільш продуктивне засвоєння індивідом екстракту несвідомих змістів» ${ }^{41}$. Однак

\footnotetext{
${ }^{36}$ Поцелуйко А.Б. Вказ. праця.-С.1. У цій роботі також визнається доведеним, «що в українських народних чарівно-фантастичних казках виявляються елементи загальноіндоєвропейських міфологічних соціофункціональних архетипів» (С.4), однак серед прикладів специфічних українських варіантів загальноіндоєвропейських архетипів чомусь з'являється архетип, що позначається словом «богатир», яке походить від давньотюркського «богатур», тобто має зовсім не українське або індоєвропейське походження, а уходить своїми коріннями в мовну практику народів алтайської мовної сім’і.

37 Забеліна Л.О. Дисертація. - С. 19

${ }^{38}$ Плахотнюк Н.О. Вказ. праця.-С. 2.

${ }^{39}$ Там же.

${ }^{40}$ Колесник О.С. Вказ. праця. - С. 1.

${ }^{41}$ Маленко С.А. Вказ. праця.-С. 11.
} 
нижче п. Маленко, говорячи про роль міфів у житті сучасної людини, рішуче змінює тональність з захопленої на загрозливу:

. . . вивільнення людини з-під тотального контролю міфу можливе лише на шляхах самопізнання, що неодмінно передбачає поступове освоєння глибинних несвідомих передумов її існування. Лише тільки внутрішнє усвідомлена консолідація свідомих та несвідомих сторін індивіду може протистояти небезпеці його отупіння та розчину в масі ${ }^{42}$.

У іншого дисертанта загроза, яку складає для сучасного людства несвідоме, описується в абсолютно апокаліптичних тонах:

... основною ознакою дійсної широкомасштабної катастрофи сучасності виступає інституційно неконтрольована повінь несвідомості, яка призводить до лавиноподібного вимивання свідомих культурних елементів з усіх галузей соціального функціонування ${ }^{43}$.

Правда, над тим, що одним 3 носіїв подібної загрози може виступати власно аналітична психологія К.-Г. Юнга, ніхто з дисертантів не замислюється.

Отже, у нашому випадку, якщо й можна говорити про критику «другого сорту», то йдеться не стільки про виявлення протиріч власно у самого Юнга, скільки про протиріччя у присвячених йому дослідженнях.

3 критикою «першого сорту» ситуація зовсім інша. Наші дисертанти досить активно користуються прагматичною реконтекстуалізацією, тобто методом критики, кваліфікованим Р. Рорті в якості першосортного. Не особливо вдаючись до аналізу численних внутрішніх проблем аналітичної психології, вони рішуче розширюють коло ㄲï смислових конотацій та імплікацій. До речі, й сам Юнг був затятим прихильником аналогічного підходу, тільки він називав це не реконтекстуалізацією, а ампліфікацією (розширенням) смислів, закладених у вихідному наративі (письмовому або усному). Деякі з ампліфікацій або реконтекстуалізацій юнгівської теорії, запропонованих вітчизняними дослідниками, особливою новизною не відрізняються, деякі виглядають досить натягнуто, однак є й декілька таких нових прочитань, які на нашу думку, можуть бути визнані оригінальними, a, можливо, й новаторськими (принаймні, за спрямуванням).

Спершу коротко про ті ампліфікації аналітичної психології, до яких вже неодноразово вдавалися - або сам Юнг, або його послідовники та дослідники. Йдеться, головним чином, про пошук паралелей юнгівському вченню в інших інтелектуальних традиціях. Наприклад, Л.О. Забєліна

${ }^{42}$ Маленко С.А. Вказ. праця.-С. 12

${ }^{43}$ Некита А.Г. Вказ. праця.-С. 2. 
ретранслює поширену думку про зв'язок Юнга та близьких до нього мислителів з гностицизмом: «У релігієзнавчих і культурологічних дослідженнях К.Г.Юнга, Д.Т. Судзукі, М. Еліаде й ін. самопізнання виступає як гностичний досвід пізнання Самості» ${ }^{44}$. С.В. Бичатін користується не менш відомою паралеллю-з платонізмом. На думку цього дослідника, архетип можна визначити як «пояснювальний опис платонівського ейдосу» ${ }^{45}$. О.С. Колесник занурюється ще глибше:

Хоча історію концепту «архетип» прийнято починати 3 праць Платона, є підстави стверджувати, що рефлексії давньогрецького філософа були лише новим етапом розвитку прадавнього уявлення про «прото-ейдоси», відомого різним міфологічним системам. В східнослов'янській традиції це оповіді про острів Буян ${ }^{46}$.

Якщо паралель з Платоном є досить тривіальною, то думку про артикуляцію в оповідях про острів Буян таких прототипів юнгівських архетипів як «прото-ейдоси», можна визнати інноваційною. Замислитися можна й над думкою про архетип як «пояснювальний опис платонівського ейдосу», або принаймні над тим, чи може бути опис пояснювалъним або, скажімо, пояснення описовим?

У деяких дисертантів є спроби зв'язати юнгівське вчення з кантівським апріоризмом. Наприклад, п. Некита говорить про «апріорні несвідомі механізми» ${ }^{47}$. Порівнював себе з Кантом і сам Юнг, однак, скажімо, впливові сучасні дослідники його спадщини вважають цю паралель досить проблематичною ${ }^{48}$. Спірною виглядає й спроба поєднати юнгівське вчення з такою впливовою академічною традицією ХХ століття, як структуралізм. Відомо, що один з його стовпів (К. Леві-Строс) дуже негативно висловлювався стосовно теорії архетипів ${ }^{49}$. Тим не менш, п. Поцелуйко, дисертація якого присвячена сама «архетипам», висловлюючись стосовно методологічної бази свого дослідження, посилається на структурну антропологію Леві-Строса та споріднені з нею напрями гуманітаристики ХХ століття ${ }^{50}$, а про Юнга не згадує. Більш сміливо налаштована авторка роботи про «міфопоетичне відтворення архетипу», яка відкрито намагається примирити Юнга із лінгвістами, семіотиками, структуралістами та Н.В. Хамітовим:

\footnotetext{
44 Забєліна Л.О. Автореферат. - С. 1.

${ }^{45}$ Бичатін C.В. Вказ. праця. - С. 8.

${ }^{46}$ Колесник О.С. Вказ. праця.-С. 7.

${ }^{47}$ Некита А.Г. Вказ. праця.-С. 1.

48 Див., напр.: Bishop P. The use of Kant in Jung's early psychological works // Journal of European Studies, xxvi (1996). - P. 107-140.

49 Див., напр.: Леви-Строс К. Структурная антропология.-М., 1985.-С. 185.

${ }^{50}$ Порівняльна індоєвропейська міфологія (Дюмезіль), структурна семіотика та лінгвістика (Іванов, Топоров, Ф.де Соссюр) (Див.: Поцелуйко А.Б. Вказ. праця. - С.3).
} 
... поняття «архетип» у сучасному розумінні з'являється в працях засновника вчення про колективне позасвідоме К.Г.Юнга. У міфологічних дослідженнях архетипам відповідають «мотиви». Досліджуючи їх, до поняття архетипу незалежно підходили В. Пропп та О. Фрейденберг, чиї праці присвячені інваріантам фольклорних та літературних наративів. Зведенням розмаїття фактичного матеріалу до найзагальніших схем займаються представники структуралізму. Цікавий синтез структурального підходу з досягненнями інших авторів знаходимо у працях ... Н. Хамітова, де представлений мета-антропологічний підхід, в якому поняття архетипу пов'язується 3 «художнім феноменом трансцендентного» ${ }^{51}$.

Ще більш широкі (й від того - ще більш сумнівні) паралелі до вчення про архетипи знаходить п. Некита, який заявляє, що «у створенні панорами соціального спотворення вихідних архетипічних принципів буття Індивіду, Природи та Суспільства» він «керувався науковими працями цілої низки сучасних західних та вітчизняних філософів». До цього списку однодумців А.Г. Некити та К.-Г. Юнга потрапили, серед інших, К. Поппер (який вважав психоаналіз псевдонаукою, тобто таким типом знання, що не піддається фальсифікації) та Е. Гуссерль (який долав психологізм). За думкою цього ж автора, аналізові «первинного вітального середовища архетипічно освоєного буття» присвятили свої роботи такі різні мислителі, як Т. де Шарден, А.Швейцер, В. Вернадський, М. Федоров, С. Рязанцев, Г. Спенсер, Ч. Ломброзо, Е. Кречмер, Ст. Гроф, О. Шпенглер ${ }^{52}$.

Складається враження, що, займаючись реконтекстуалізацією Юнга у власних прагматичних цілях, деякі дисертанти свідомо чи мимоволі скористалися головним принципом епістемологічного анархізму П.Фейерабенда - anything goes. Якщо так, то не дуже дивно виглядає й паралель, що прочитується у іншого автора, в роботі якого «окреслюється первинна дефініція поняття «архетип колективного несвідомого» як відкритої системи, що самоорганізується» ${ }^{53}$. Можливо, це досить перспективна ампліфікація-реконтекстуалізація, але, на нашу думку, намагання говорити мовою постнекласичної науки про мислителя, якого логічніше було б віднести до неоромантиків або навіть до традиціоналістів, $є$ надто сильною модернізацією. I, взагалі, якщо й шукати паралелі юнгівському вченню в сучасній науці, то радше слід згадати не про синергетику, а про їі старшу сестру-суперницю - кібернетику. Принаймні, архетип, як він окреслюється самим Юнгом, скоріше нагадує кібернетичне, а не синергетичне явище. Архетипи у Юнга не стільки спонукають до розвитку у напрямку чогось нового (принцип позитивного зворотного зв'язку, характерний

\footnotetext{
${ }^{51}$ Колесник О.С. Вказ. праця.- С. 2

${ }^{52}$ Некита А.Г. Вказ. праця. - С. 3-4

${ }^{53}$ Маленко С.А. Вказ. праця.-С. 4 .
} 
для синергетичних систем), скільки постійно повертають нас до вихідного, примордіального досвіду (принцип негативного зворотного зв'язку, що характерний саме для кібернетичних систем).

До речі, й сам автор «синергетичної» інтерпретації архетипів в іншому місці говорить про них скоріше як про кібернетичну матрицю, що не дозволяє нашій свідомості доходити у своїх флуктуаціях аж до точок біфуркації з подальшим перетворенням вихідної системи на абсолютно нову: «Свобода свідомості людини виражається не в протиставленні себе як сутності архетипам, а в творчій самореалізації через вже презадані способи гармонізації їі зовнішнього та внутрішнього світу ...- через форми трансформації поведінки людини, сформульовані насамперед у міфах» ${ }^{54}$. Подібної точки зору дотримується й інший дисертант, за думкою якого, «Розвиток людської культури, її мета, на думку К.Г. Юнга, це рух в сторону колективної свідомості, яка б увібрала свою несвідому основу. $<\ldots>$ Основою культури, її творцем, носієм сенсу виступає індивід, але лише той індивід, який усвідомив своє несвідоме...» ${ }^{55}$. Однак, в цьому пасажі прослуховується вже не стільки новомодна синергетична фразеологія, скільки стара й добре відома марксистська гадка про те, що є така необхідність, без усвідомлення якої нам всім свободи ніколи «нє відать».

Саме спроба поєднати аналітичну психологію з марксизмом є однією з найбільш оригінальних ампліфікацій-реконтекстуалізацій вчення Юнга, знайдених нами в дисертаціях вітчизняних дослідників. Автор роботи «Механізми несвідомого соціального спотворення феноменології архетипу» стверджує:

Провідна для філософії К. Маркса ідея відчуження та діяльнісно знімаючого його «позитивного гуманізму», що представлена у «Економіко-філософських рукописах 1844 року», неодмінно набуває нових імпульсів у поєднанні з теорією архетипів колективного несвідомого швейцарського мислителя-гуманіста К.Г.Юнга ${ }^{56} .<\ldots>$ Теоретико-методологічною основою роботи є: ... принцип матеріалістичного розуміння історії в поєднанні з принщипами аналітичної психології ${ }^{57}$.

Так, з легкої руки М. Фуко та П. Рікьора в філософських колах вже давно й плідно використовується поняття «філософії підозри», під яке підпадають, окрім Ф.Ніцше, також й засновники психоаналізу (З. Фрейд) та діалектичного/історичного матеріалізму (К. Маркс). Однак, про спорідненість марксизму з юнгізмом авторові даної статті чути ще не доводи-

\footnotetext{
${ }^{54}$ Маленко С.А. Вказ. праця.-С. 7.

${ }^{55}$ Бичатін C.В. Вказ. праця. - С. 14.

${ }^{56}$ Некита А.Г. Вказ. праця. - С. 3.

${ }^{57}$ Некита А.Г. Вказ. праця.-С. 5.
} 
лось. На тлі таких зривачів покровів, переоцінників всіх цінностей, руйнівників існуючих традицій, як Маркс, Ніцше та Фрейд, Юнг виглядає скоріше як закоренілий консерватор. Тим не менш, п.Некита пропонує досить розгорнуту аргументацію на користь можливості поєднання Маркса з Юнгом. В його роботі «обгрунтовується специфіка інституційного спотворення вихідного суспільного призначення Людини, яке несвідомо консервується в іміджі Соціального Індивіда» 58 .

Механізми інституційного спотворення, як з сумом констатує А.Г. Некита, безжалісно втручаються навіть у найсакральніші сфери людського буття. Наприклад, один з параграфів дисертації присвячується доказу того, що на такому архетиповому феномені, як віра, давно й жорстоко паразитує така ï соціально спотворена форма, як релігія, яка «офіційно сакралізує сама себе, як самодостатню інституційну форму справжнього знання та досвіду» ${ }^{59}$. Справжню (архетипову) віру протягом майже усієї людської історії спотворює «ініційована та санкціонована державою інституалізація релігійної віри» ${ }^{60}$. Результатом цього $є$ тотальне відчуження: «Формалізація віри, як природного способу покладання та вираження людиною своєї сутності, з необхідністю ритуалізує її соціальне перебування, поглиблює процеси відчуження індивідуального духовного досвіду» ${ }^{61}$.

Не менш драматичні процеси спостерігаються й в інших сферах людської діяльності, скажімо, у галузі виробництва та споживання. Один з параграфів дисертації п. Некити ( «Товарно-пропагандистська апологетика масового споживання Життя») присвячений спотворенням архетипової сутності людини шляхом реклами, яка, за словами дисертанта, $є$ виключно комерціалізованою формою «експонування та експлікації „буття“ групових несвідомих уявлень у сфері консервуючої технології соціальних презентацій товару» ${ }^{62}$. Остаточні висновки до всієї дисертації звучать майже як вирок всім формам соціальної інституціалізації, які колинебудь з'являлися на цьому світі:

Соціальність та ієрархія її інституалізації постають модусами спотворення феноменології архетипу на рівні індивіда та суспільства виключно у формі несвідомого відчуження; практика штучної атомізації та антагонізації етапів природної феноменології архетипу неминуче огортається несвідомим пануванням соціально девіталізованих та дефеноменологізованих значень-значущостей, які формально дискредитують онтологічні архетипічні змісти... ${ }^{63}$

${ }^{58}$ Некита А.Г. Вказ. праця. -С. 11.

${ }^{59}$ Некита А.Г. Вказ. праця.-С. 12.

${ }^{60}$ Там же.

${ }^{61}$ Там же.

${ }^{62}$ Некита А.Г. Вказ. праця.-С. 13.

${ }^{63}$ Некита А.Г. Вказ. праця.-С. 14. 
На нашу думку, оригінальність цієї дисертації полягає, якщо можна так висловитися, у надзвичайно витонченому опортунізмі. 3 одного боку, її автор нищівно критикує всі соціальні структури, які, на його думку, є безнадійно спотвореними формами людського буття - цариною тотального відчуження. Однак вирішення цієї глобальної проблеми, яке ми знаходимо у п.Некити, принципово відрізняється від того, що запропонував інший борець з відчуженням. На відміну від К. Маркса, п. Некита не закликає людство до всесвітньої революції, а пропонує повернутися до архетипових істин, прихованих в нашому несвідомому. Такий собі випуск марксистської масової революційної пари через індивідуально налаштовані охолоджувальні балони юнгіанської психотерапії. Досить м'який та мирний фінал.

Загрозливі нотки є також і в роботі під назвою «Слово як архетип культури» 64 . Слово, якщо його розглядати саме як «архетип культури», може, як виявляється, виконувати роль «меча духовного» у процесі становлення нації ${ }^{65}$. Однак й тут все закінчується досить миролюбно. Оскільки українська нація ${ }^{66}$, за думкою авторки дослідження, етап становлення вже пройшла, зараз йдеться радше про «етно-креативну функцію» 67 слова як архетипу: «Слово стає святинею для української нації, проявляється його самоохоронна і утверджуюча функція. Воно асоціюється 3 храмом етносу, збереження якого прирівнюється до способу виживання української спільноти» ${ }^{68}$. Тобто архетипово-словесний меч, який трошки обнажила ця дисертантка, принаймні на даному етапі розвитку української нації можна знов сховати до піхв.

Отже, якщо довіритися п.Плахотнюк, використовувати архетип як зброю вже немає потреби, а від зближення Юнга з Марксом у роботі п.Некити революційна іскра скоріше загасла. Разом з тим, заспокоюватися не варто, бо іноді революція приходить зовсім не звідти, звідки на неї чекали у першу чергу. В нашому випадку по-справжньому революційні висновки були отримані дисертанткою, яка спробувала ампліфікувати Юнга за допомогою винаходів сучасних гендерних студій. Л.О. Забєліна у висновках до своєї роботи пише:

В связи с расширением знаний культурологического, социальнопсихологического и религиозно-философского концепта Самости,

\footnotetext{
${ }^{64}$ Можливість розглядати архетип у зв'язці із словом виникла у авторки цього дослідження завдяки творчому синтезу юнгівського розуміння архетипу з низкою інших підходів, започаткованих, головним чином вітчизняними фахівцями: С.Кримським, Ю. Павленком та Н. Хамітовим (Див.: Плахотнюк Н.О. Вказ. праця. - С. 2.)

${ }^{65}$ Плахотнюк Н.О. Вказ. праця. - С. 18.

66 Дисертантка зосередила свою увагу саме на «функціонуванні архетипу Слова в духовному світі українського народу» (Див.: Плахотнюк Н.О. Вказ. праця. - С. 2.).

${ }^{67}$ Плахотнюк Н.О. Вказ. праця.- С. 18.

${ }^{68}$ Плахотнюк Н.О. Вказ. праця.-С. 17.
} 
также следует отметить и гендерные исследования, получившие в настоящее время широкое развитие. Согласно перформативной теории гендерной идентичности, не существует истинной природы женщины или мужчины, вытекающих из их телесных особенностей $<\ldots>$ Эта идея послужила началом для развития концепции Сандры Бем, в основе которой лежит понятие андрогинии, согласно которой любой человек, независимо от его биологического пола, может соединить в себе традиционно мужские или традиционно женские качества. Гендерные исследования предлагают не только новое объяснение человека и общества, но и ставят перед собой цель формирования общества андрогинии. Это центральное положение гендерной теории еще раз подтверждает стремление человека к своим истокам, к Самости, не имеющей в своем основании никаких противоположных проявлений 69

Виявляється, що об'єднання юнгівського вчення про архетип Самості з перформативною теорією гендерної ідентичності може призвести, серед іншого, й до ствердження про необхідність будувати суспільство андрогінів. Нам здається, що оцінювати цей заклик (або констатацію?) - не дуже вдячна справа. Можна легко втратити політкоректність та мимоволі стати ворогом всього гендерного руху. Тому підсумуємо просто: поживемо побачимо.

Інша справа - деякі, так би мовити, дрібніші інтерпретації Юнга, які присутні в роботі п. Забєліної. Тут можна й посперечатися. Згідно з п. Забєліною, «Центральным понятием психотерапии Юнга является «индивидуализация» (курсив мій.- В.М.). Под индивидуализацией в аналитической психологии понимают движение от фрагментарности к целостности души, о переходе от «Я», центра сознания, к «Самости» как центру всей психической системы». Більш того, за словами дисертантки, Юнг сам писав: «Индивидуализация (курсив мій.-B.М.) означает: стать единичной сущностью и, поскольку под индивидуальностью мы понимаем нашу глубинную внутреннюю, предельную и ни с чем не сравнимую уникальность, - стать собственной Самостью. В силу этого „индивидуализацию“ (курсив мій. - В.М.) можно было бы переводить как „самосозидание“ и „самовоплощение“» 70 . Парадоксально, але факт: У російськомовному перекладі, на який посилається п. Забєліна ${ }^{71}$, все абсолютно так. За маленьким виключенням: в обох місцях, де Забєліна пише «индивидуализация», написано «индивидуация». Що це: Проста описка дисертантки? Помилка перекладу (своєрідне lost-in-translation), яку своєчасно підмітила та ви-

\footnotetext{
69 Забеліна Л.О. Дисертація.-С. 159.

70 Забеліна Л.О. Дисертація. - С. 28

${ }^{71}$ Юнг К.Г. Божественный ребенок: Аналитическая психология и воспитание / Пер. с англ. Д.В. Дмитриева, Т.А. Ребеко. - М.: Олимп, АСТ-ЛТД, 1997. - С. 390.
} 
правила п. Забєліна? Або її нове прочитання одного з центральних понять аналітичної психології К.-Г. Юнга?

Перше припущення (випадкова описка Л.А. Забєліної) доводиться відкинути після більш детального ознайомлення з текстом її дисертації. Наприклад, в іншому місці вона цитує фрагмент із ще одного твору Юнга: «Индивидуализация (курсив мій.-B.М.) представляет собой mysterium coniunctionis...» ${ }^{72}$. Однак у перекладі, на який вона посилається (цього разу це ще й інший перекладач), знов-таки, є маленька відмінність: «Индивидуация (курсив мій. - В.М.) представляет собой mysterium coniunctionis...» ${ }^{73}$. Ще в одному місці у Забєліної: «Единство камня эквивалентно индивидуализации (курсив мій.--В.М.)» ${ }^{74}$, тоді як у перекладі, на який вона посилається: «Единство камня эквивалентно индивидуации (курсив мій. - B.M.)» ${ }^{75}$.

Важко повірити в те, що різні перекладачі уперто припускалися однієї й тієї ж помилки. Навпаки, вони мали рацію. Річ у тім, що Юнг сам неодноразово підкреслював, що під індивідуацією в аналітичній психології мається на увазі дещо суттєво відмінне від індивідуалізації. Для юнгіанства це в буквальному смислі азбучна істина. Наприклад, у відповідній статті автори словника аналітичної психології наводять канонічну фразу самого Юнга:

Индивидуализм означает скорее умышленное предпочтение особых личных качеств, чем коллективных соображений и обязательств. Индивидуация же означает более полную реализацию коллективных качеств ${ }^{76}$.

Тобто, доводиться визнати, що правильною була наша третл гіпотеза: п. Забєліна не припустилася випадкової описки (бо описки не робляться так регулярно), п. Забєліна не виправила помилку перекладачів (бо вони просто слідували букві та духові юнгівської теорії), а скоріше за все вирішила трошки переосмислити Юнга. Правда, остаточного завершення цей творчий процес не набув. В цілому термін «индивидуализация» з'являється в роботі Л.А. Забєліної більш 10 разів, однак в одному місці процес, який вона намагається ним позначити, з'являється й під своїм власним ім'ям: «По мнению Юнга, то, что выражает символизм алхимии, составляет проблему развития личности в процессе индивидуации (курсив мій. - В.М.)» ${ }^{77}$.

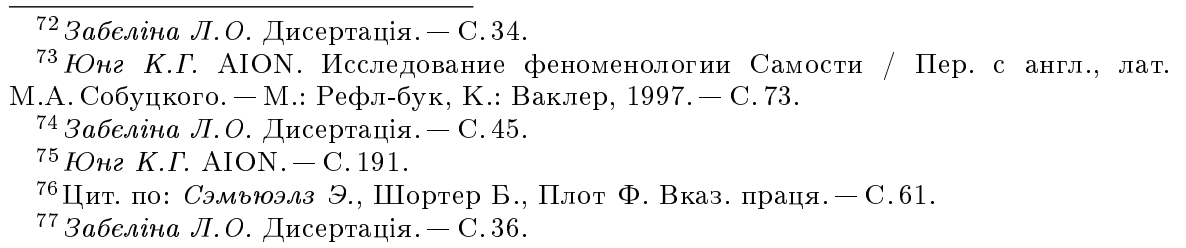


Є в дослідженні п. Забєліної й ще декілька «мікро-інтерпретацій» вчення Юнга, які, відповідно, викликають вже зовсім дрібні зауваження. Коли вона пише, що «зміст колективного несвідомого складають попередні, споконвічні форми» ${ }^{78}$, виникає бажання спитати: чи можуть форми складати зміст? Коли говориться, що «над индивидуальным бессознательным Юнг возвел фундамент коллективного бессознательного» ${ }^{79}$, виникає інтерес: що це за фундамент, який зводиться над? Коли заходить розмова не про співвідношення несвідомого та свідомості, п. Забієліна в одному місці пропонує більш правдоподібну (з «інженерної» точки зору) конструкцію: «само сознание являясь продуктом досознательной психической жизни, покоится на (курсив мій. - В.М.) бессознательных предпосылках ${ }^{80}$, хоча декількома реченнями нижче й ця проста та ясна схема трошки проблематизується й саме свідомість стає свого роду фундаментом: «...феномен сознания. Ведь практически без него нет никакого мира. Он может существовать как таковой только тогда, когда есть психика, сознательно рефлексирующая и выражающая его. Таким образом, сознание выступает как одно из условий бытия» ${ }^{81}$.

Однак, повторимося, все це дрібниці. Головне, що, як каже дисертантка у висновках:

Проведенное исследование, на наш взгляд, имеет фундаментальное эвристическое значение для компаративистских (культурологических и философских) истолкований различных культур. Оно какбы (так написано в оригіналі. - В.М.) указывает путь к построению некой «философии надежды», которая найдет адекватные способы открытого культурного диалога Запада и Востока... ${ }^{82}$.

Можливо, наше власне нерозуміння деяких із знахідок (зокрема й тих, що вказують шлях до побудови «філософії надії») цієї евристично насиченої дисертації обумовлено незнанням деяких з методологічних засад, якими керувалася авторка роботи під час її написання та захисту:

В исследовании использованы методы дескриптивного эксплицирования, а также герменевтико-феноменологический, интервальный и компаративный подходы. Сущность дескриптивного эксплицирования в данном случае состояло в аналитическом выявлении, с опорой на широкий массив священных писаний (как мировых, так и национальных религий), с последующим описанием представлений

\footnotetext{
78 Забеліна Л.О. Автореферат. - С. 6.

79 Забеліна Л.О. Дисертація.-С. 19.

80 Забеліна Л.О. Дисертація.-С. 17.

${ }^{81}$ Там же.

82 Забеліна Л. О. Дисертація.-С. 161.
} 
гностического характера, выражающих архетип Самости, символически представленный в архетипичном образе андрогина. Этот метод сочетается с герменевтико-феноменологическим, который применялся в том случае, когда проводилось исследование и анализ философских работ, посвященных рассмотрению гностического «объединяющего» символа. Два этих метода использовались тогда, когда требовалось обращаться к письменным источникам традиций, к их интерпретациям, и к развитию их философских идей. При исследовании многомерных контекстов использовался интервальный подход. В тех случаях, когда требовалось провести сравнение отдельных систем мысли, различных подходов к проблеме или выявить разницу между философскими понятиями и категориями был использован компаративный метод. В качестве операционального метода истолкования феномена Самости был применен юнгианский метод исследования культуры ${ }^{83}$.

Є підозра (чи, все ж таки, надія?), що різноманітні витончені методи дослідження, особливо, скажімо, такі, як метод «дескриптивного эксплицирования» або «интервальный подход», принесуть вітчизняній науці ще багато нових неординарних переосмислень ідей Карла Густава Юнга. Отже, чекатимемо на нові пригоди архетипів.

${ }^{83}$ Забеліна Л.О. Дисертація.-С. 10-11. 